\title{
Financial Performance Analysis at PT Bank Muamalat Indonesia, Tbk.
}

\author{
M.Thoyib ${ }^{1}$ Rita Martini $^{1}$ Tarisa Salsabella ${ }^{1, *}$ Marsahanda Aprilia $^{1}$
}

\author{
${ }^{1}$ State Polytechnic of Sriwijaya \\ ${ }^{*}$ Corresponding author.Email: tarisasalsabella2@gmail.com
}

\begin{abstract}
Financial statement analysis is a very important tool to obtain information about the financial condition and performance of the company during the period. By analyzing the financial statements, it can be seen whether the financial performance of a bank is in a healthy or unhealthy condition. The cause of a bank is said to be healthy if the ratio is above the predetermined average and is said to be unhealthy if the ratio value is below the average. The object of this research is one of the banks in Indonesia, namely PT Bank Muamalat Indonesia Tbk. This study was conducted to predict financial performance using the Camel method. This bank is the first Islamic bank that was established in 1991. Based on the financial reports from the official website of PT Bank Muamalat Indonesia Tbk, profits fluctuate from year to year, and the amount of costs incurred is almost the same as the income received. This study aims to (1) determine the causes of the rise and fall of profits for three consecutive years; (2) to determine and analyze the impact of the amount of costs incurred by PT Bank Muamalat Indonesia Tbk. In this study it is known that in 2018 the bank was said to be in a healthy enough condition with a camel ratio of $67.91 \%$, which was between $66-<81 \%$ with the bank's health standard that had been determined. In 2019 the bank was said to be unwell condition with camel ratio of $62,92 \%$ and In 2020 PT Bank Muamalat Indonesia experienced the same conditions as in 2019 which was in Unwell condition.
\end{abstract}

Keywords: Financial Performance, Camel analysis.

\section{INTRODUCTION}

One sector that is able to develop rapidly and support the national economy as well as play a major role in national development is the banking sector. Bank is a business entity that collects funds from the public in the form of savings and distributes them back to the community in the form of credit and other forms, such as requiring business capital through micro, small and medium enterprises. The banking sector has grown dynamically since the issuance of Law No. 10 of 1998 concerning banking which provides greater opportunities for Islamic banking.

Assessment of bank soundness level can be seen from various aspects. This assessment aims to determine whether the bank is in a healthy condition, healthy enough, unhealthy, and unhealthy so that Bank
Indonesia as the supervisor and supervisor of the banks can provide direction or instructions regarding how the bank should operate or even stop its operations. The decline in public deposits has made the banking industry try to maintain the funds they have to maintain bank liquidity by providing high interest rates. Lidia and Fernando, (2017) say that: CAMEL analysis is used to analyze and evaluate the financial performance of commercial banks in Indonesia. CAMEL analysis is regulated in Bank Indonesia Regulation Number 6/10/PBI/2004 concerning the Rating System for Commercial Bank Soundness Level and Bank Indonesia Regulation Number 9/1/PBI/2007 concerning Commercial Bank Soundness Level Assessment System Based on Sharia Principles.

The first Islamic bank in Indonesia which was established in 1991 was Bank Muamalat Indonesia 
(BMI) as the only bank at that time that carried out business activities with the principle of profit sharing and which managed to exist and even gained significant profits during the monetary crisis in mid 1997-1998 in Indonesia. This study will analyze the financial performance of PT Bank Muamalat Indonesia, Tbk. using the CAMEL method. The data used includes statements of financial position and income statements for three consecutive years, 2018, 2019, and 2020, with the title Financial Performance Analysis at PT Bank Muamalat Indonesia, Tbk.

\section{LITERATURE REVIEW}

Ismail (2013) states that the Bank is a financial institution whose main function is to collect funds from the public, channel funds to the public, and also provide services in the form of banking services.

Financial report is a form of reporting consisting of Balance Sheet and Profit Calculation and Statement of Changes in Equity. The balance sheet shows or describes the total assets, liabilities and capital of a company on a certain date. While the Profit and Loss Calculation (report) shows the results that have been achieved by the company and the expenses incurred during a certain period, and the Capital Change Report shows the sources and uses or reasons that cause changes in the company's capital [7].

Financial performance is a description of a bank's financial condition in a certain period, both in terms of raising funds and distributing funds, which are usually measured by indicators of capital adequacy, liquidity, and bank profitability [5].

The CAMEL analysis method aims to assess or measure the soundness of banks based on financial ratios that emphasize five aspects, namely capital, asset quality, management, income, and liquidity.

Bank assessment is carried out based on Bank Indonesia regulation Number 6/10/PBI/2004 and the circular letter of Bank Indonesia Number 6/23/DPNP/31 may 2004 in CAMEL (Capital, Asset, Quality, Earnings, and Liquidity).

\section{RESEARCH METHODOLOGY}

This research can be categorized as descriptive research. Descriptive method is a method used to describe or analyze a research result but is not used to make broader conclusions [8]. So, it can be concluded that the descriptive method is a method in which research only collects, composes and classifies data so that it can get a clear picture of the problem under study. This study uses quantitative data to calculate data which is a financial report to analyze the health condition of PT Bank Muamalat Indonesia Tbk. by using the Camel method consisting of (Capital, Asset quality, Management, Earning, Liquidity).

The type of data used in this study is quantitative, namely data in the form of explanations/statements in the form of notes or numbers that can be operated mathematically. The data used are financial statements (statement of financial position and statement of profit/loss). By studying, observing and analyzing documents related to the object of research.

Data source

Sanusi (2016:104) explains that secondary data is data that is available and collected by other parties. Related to secondary data, researchers just use the data according to their needs. Secondary data taken by the author was obtained from the official website of PT Bank Muamalat Indonesia Tbk through the website (www.bankmuamalat.co.id) which includes the position statement and profit and loss statement of PT Bank Muamalat Indonesia Tbk.

\subsection{Analysis Techniques}

The analytical technique used by the researcher is descriptive analysis technique with the data method used is the Camel method (Capital, Asset quality, Management, Earning, Liquidity).

1. Capital Adequacy Ratio (CAR)

Capital is the funds invested by the owner at the time of establishment of the bank intended to finance the bank's business activities. The capital factor can be measured using the Capital Adequacy Ratio (CAR) formula. CAR is a ratio that measures the capital adequacy of a bank which is calculated based on the ratio of total capital to risk-weighted assets .CAR is an indicator of a bank's ability to cover a decrease in its assets as a result of bank losses caused by risky assets

The value of the increased CAR ratio will result in increased profits. The formula for calculating CAR is:

$$
\mathrm{CAR}=(\text { Capital } / \mathrm{ATMR}) \times 100 \%
$$

To calculate the credit score using the following formula:

Credit Value CAR Ratio $=1+($ CAR RATIO $)(0,1 \%) \times 1$

\section{Asset quality}

Productive asset quality reflects the financial performance of banking companies. Asset quality assessment is carried out by comparing earning assets classified with total earning assets in accordance with 
Bank Indonesia regulations. Calculation of classified earning assets assessed from current loans at $0 \%$, special mention loans at 25\%, substandard loans at $50 \%$, doubtful loans at $75 \%$ and bad loans at $100 \%$. One of the measures of bank soundness based on asset quality aspects can be seen from the Earning Asset Quality (KAP) ratio which can be formulated as follows:

KAP ratio $=(($ Classified earning assets $) /($ Total earning assets) $) \times 100 \%$

For the calculation of the credit score, the KAP ratio is formulated as follows:

KAP Ratio Credit Value $=1+\quad((15.50-\mathrm{KAP}$
$\mathrm{RATIO}) /(0 \quad 15 \%) \mathrm{x} 1$

\section{Management (management)}

Bank soundness level from management aspect can be measured quantitatively by calculating Net Profit Margin (NPM). This financial ratio measures the level of the bank's ability to generate net profit from its main operational activities.

The formula for calculating the NPM ratio is as follows: $\mathrm{NPM}=(($ Net Profit $) /($ Operational Income $)) \times 100 \%$

\section{Earnings}

One of the parameters to measure the soundness of a bank is the bank's ability to earn profits. The assessment is based on the profitability or earnings of a bank, namely seeing the ability of a bank to create profits.

Assessment in this element is based on two kinds, namely:

1. To measure the health of the bank from the income aspect, the Return on Assets (ROA) ratio can be used by comparing the net profit achieved with the total assets owned by the bank.

The ROA value can be calculated using the following formula:

$\mathrm{ROA}=(($ Profit before tax $) /($ Total assets $)) \times 100 \%$

The calculation of the ROA Ratio Credit Value uses the following formula:

NK ROA Ratio $=(($ ROA Ratio $) /(0.015 \%))$

2. To measure the health of the bank from the income aspect, the ratio of Operating Expenses to Operating Income (BOPO) can be used. The formula for calculating $\mathrm{BOPO}$ is:

$\mathrm{BOPO}=(($ Operational $\quad$ Expenses $) /($ Operational
Income $) \times 100 \%$

The formula for calculating the BOPO Credit Value is as follows:

BOPO Credit Value $=((100 \%-B O P O$ Ratio $) / 0.08) \times 1$

\section{Liquidity Calculation (Liquidity)}

The assessment of liquidity is carried out with the value of two ratios, namely the ratio of Net Interbank Liabilities to Core Capital and the ratio of credit to funds received by the Bank. What is meant by Interbank Net Liability is the difference between bank liabilities and claims to other banks. Meanwhile, the Funds Received include Bank Indonesia Liquidity Credit, Current Accounts, Time Deposits, and Community Savings, Non-bank loans with maturities of more than three months (excluding subordinated loans), Time Deposits and Loans from other banks with maturities of more than three months. three months, and securities issued by banks with maturities of more than three months.

The soundness of commercial banks can be seen from two sides, namely qualitative and quantitative. From the qualitative side, it is seen from the manager, history, owner. The quantitative side can be seen from the ratio of liquidity, solvency, profitability, capital adequacy and Loan Deposit Ratio.

The formula for the Loan Deposit Ratio is as follows:

LDR $=($ Loans/Deposits $) \times 100 \%$
The formula for calculating the LDR Ratio Credit Value
is as follows.
$\begin{aligned} & \text { Credit Value LDR Ratio }=((115 \% \text {-LDR } \\ & \text { Ratio } /(0.25 \%))\end{aligned}$

\section{RESULT AND ANALYSIS}

After calculating and knowing the ratios from the bank's financial statements and the credit score of each ratio, the soundness of PT Bank Muamalat Indonesia Tbk can be determined using the CAMEL method in Table 1.

Table 1 Bank Health Level

\begin{tabular}{|c|c|}
\hline Credit Score & Predicate \\
\hline $81-100$ & Healthy \\
\hline $66-<81$ & Healthy Enough \\
\hline $51-<66$ & Unwell \\
\hline $0-<51$ & Not Healthy \\
\hline
\end{tabular}

Source: Lidia dan Fernando (2017) 
Discussion on Health Level in 2018

Table 2 Bank Health Level

\begin{tabular}{|l|l|l|l|l|l|}
\hline Year & $\begin{array}{l}\text { Camel } \\
\text { Factor }\end{array}$ & $\begin{array}{l}\text { Ratio } \\
\text { Value } \\
(\%)\end{array}$ & $\begin{array}{l}\text { Credit } \\
\text { Score }\end{array}$ & $\begin{array}{l}\text { Weight } \\
(\%)\end{array}$ & $\begin{array}{l}\text { Camel } \\
\text { Score } \\
(\%)\end{array}$ \\
\hline \multirow{5}{*}{2018} & CAR & 12,34 & 100 & 30 & 30 \\
\cline { 2 - 6 } & KAP & 4,48 & 74,46 & 30 & 22,34 \\
\cline { 2 - 6 } & NPM & 2,56 & 2,56 & 20 & 0,51 \\
\cline { 2 - 6 } & ROA & 0,80 & 53,3 & 5 & 2,66 \\
\cline { 2 - 5 } & BOPO & 96,15 & 48,125 & 5 & 2,40 \\
\cline { 2 - 5 } & LDR & 38,86 & 100 & 10 & 10 \\
\cline { 2 - 5 } & Number of Camel value & 67.91 \\
\cline { 2 - 5 } & Bank Health & $\begin{array}{l}\text { Healthy } \\
\text { Enough }\end{array}$ \\
\hline
\end{tabular}

Source: Processed data (2021)

In 2018 PT Bank Muamalat Indonesia Tbk obtained a CAMEL value of $67.91 \%$, then the bank is said to be in ENOUGH HEALTHY because it is between $66 \%$ $<81 \%$ which indicates the bank's condition is in accordance with the predetermined bank soundness level.

\section{Discussion on Health Level in 2019}

Table 3 Bank Health Level

\begin{tabular}{|c|l|l|l|l|l|}
\hline Year & $\begin{array}{l}\text { Camel } \\
\text { Factor }\end{array}$ & $\begin{array}{c}\text { Ratio } \\
\text { Value } \\
(\%)\end{array}$ & $\begin{array}{c}\text { Credit } \\
\text { Score }\end{array}$ & $\begin{array}{c}\text { Weight } \\
(\%)\end{array}$ & $\begin{array}{c}\text { Camel } \\
\text { Score } \\
(\%)\end{array}$ \\
\hline \multirow{5}{*}{2019} & CAR & 12,41 & 100 & 30 & 30 \\
\cline { 2 - 6 } & KAP & 4,77 & 72,53 & 30 & 21,76 \\
\cline { 2 - 6 } & NPM & 1,04 & 1,04 & 20 & 0,21 \\
\cline { 2 - 5 } & ROA & 0,051 & 3,4 & 5 & 0,17 \\
\cline { 2 - 5 } & BOPO & 98,75 & 15,625 & 5 & 0,78 \\
\cline { 2 - 5 } & LDR & 38,51 & 100 & 10 & 10 \\
\hline \multirow{2}{|l|}{ Number of Camel value } & 62,92 \\
\hline
\end{tabular}

Source: Processed data (2021)

In 2019 PT Bank Muamalat Indonesia Tbk obtained a CAMEL value of $62.92 \%$, then the bank is said to be in LESS HEALTHY because it is between $51-<66$ which indicates the bank's condition is in accordance with the predetermined bank soundness level. In 2019 the condition of PT Bank Muamalat Indonesia Tbk continued to decline due to a decrease in profit and revenue acquisition which was almost the same as the costs incurred.
Discussion on Health Level in 2020

Tabel 4 Bank Health Level

\begin{tabular}{|c|c|c|c|c|c|}
\hline Year & $\begin{array}{l}\text { Camel } \\
\text { Factor }\end{array}$ & $\begin{array}{l}\text { Ratio } \\
\text { Value } \\
(\%)\end{array}$ & $\begin{array}{l}\text { Credit } \\
\text { Score }\end{array}$ & $\begin{array}{l}\text { Weight } \\
(\%)\end{array}$ & $\begin{array}{l}\text { Camel } \\
\text { Score } \\
(\%)\end{array}$ \\
\hline \multirow{8}{*}{2020} & CAR & 15,21 & 100 & 30 & 30 \\
\hline & KAP & 5,33 & 68,8 & 30 & 20,6 \\
\hline & NPM & 0,73 & 0,73 & 20 & 0,14 \\
\hline & ROA & 0,029 & 1,93 & 5 & 0,09 \\
\hline & BOPO & 98,79 & 15,125 & 5 & 0,75 \\
\hline & LDR & 38,61 & 100 & 10 & 10 \\
\hline & \multicolumn{4}{|c|}{ Number of Camel value } & 61.58 \\
\hline & \multicolumn{4}{|c|}{ Bank Health } & Unwell \\
\hline
\end{tabular}

Source: Processed data (2021)

In 2020 PT Bank Muamalat Indonesia Tbk obtained a CAMEL value of $61.58 \%$, then the bank is said to be in a LESS HEALTHY state because it is between $51-<66$ which indicates the bank's condition is in accordance with the predetermined bank soundness level

\section{CONCLUSION}

1. The Capital Adequacy Ratio (CAR) owned by PT Bank Muamalat Indonesia Tbk has increased continuously, this is said to be a HEALTHY bank condition because the CAR Ratio value is $>8 \%$.

2. The quality of productive assets (KAP) of PT Bank Muamalat Indonesia Tbk during 2018 to 2020 has good asset quality, this is said to be a HEALTHY bank condition because the ratio value is between $0 \%-<10.35 \%$.

3. The Net Profit Margin (NPM) owned by PT Bank Muamalat Indonesia Tbk continues to decline every year, this is said to be an UNHEALTHY bank condition because the ratio value is $<51 \%$ due to a decrease in profits from 2018-2020.

4. Based on the ratio of Return on Assets (ROA) during 2018 to 2020 PT Bank Muamalat Indonesia and BOPO this is said to be the condition of the bank is NOT HEALTHY because ROA value $<0.76 \%$ and BOPO Ratio $>95.92 \%$. This is because the costs incurred resemble the income received by the Bank.

5. Loan to Deposit Ratio (LDR) has good quality in paying its debts when viewed from the deposits of PT Bank Muamalat Indonesia Tbk, this is said to be a HEALTHY bank condition because the LDR ratio is $<94.75 \%$. 


\section{REFERENCES}

[1] Desiana, L. \& F. A. (2017). Analisis Laporan Keuangan. Noer Fikri.

[2] Hery. (2015). Analisis Laporan Keuangan. Center for Academik Publishing Service.

[3] Hery. (2020). Bank Dan Lembaga Keuangan Lainnya. PT Grasindo.

[4] Ismail. (2012). Akuntansi Bank (Ke-3). Kencana.
[5] Jumingan. (2014). Analisis Laporan Keuangan (Ke5). PT Bumi Aksara.

[6] Muhamad. (2020). Bank \& Lembaga Keuangan Syariah. PT Raja Grafindo Persada.

[7] Munawir (2014). Analisis Laporan Keuangan. Liberty.

[8] Sugiyono. (2016). Metode Penelitian Kuantitatif, Kualitatif dan $R \& D$. Alfabeta.

[9] Laporan Keuangan PT Bamk Muamalat Indonesia Tbk https://www.bankmuamalat.co.id/ 